\title{
Sochi region city planning for the post-Olympic period
}

\author{
Yuriy Dreizis ${ }^{1, *}$, Nina Anisimova ${ }^{1}$, Guram Darakchyan ${ }^{1}$ and Aida Karamova ${ }^{1}$ \\ ${ }^{1}$ Sochi State University, 26-A Sovietskaya str., Sochi, 354000, Russia
}

\begin{abstract}
Conceptual approaches to development of the region during the post-Olympic period are presented in the article. Conclusions that after the end of the Olympic Games, the region of their carrying out faces the recessive period are drawn. At the same time, tasks of finding new growth points and development of strategy of further development of the region based on improvement under the new conditions of the General plan come out on top in such conditions. The main directions of further social and economic development of the Sochi resort agglomeration are considered. It is shown that further development of economy and infrastructure of Sochi and creation of conditions for its accelerated development during the postOlympic period are possible only on the basis of the strategized General plan of the city.
\end{abstract}

\section{Introduction}

Town-planning history of the resort region of Sochi has its own features. Its development goes especially quickly and the prospect of the brilliant future as a resort is obvious. The reason of it is unusually favorable, unique even for the Black Sea coast a combination in the Sochi region of climatic conditions which are necessary for creation of the climatic resort area here.

Sochi is a special territory of investment attractiveness and development of the infrastructure. It has won this right to be called the resort center of Russia thanks to the geographical location and climatic conditions.

Complex development of the region was provided within the ended Federal Program of development of Sochi as mountain-climatic resort (2006-2014), which approved in 2006. The Program provided multiple scenarios of improvement of development of all levels of systems and problems of regional development. The major task that has melted in this program is to keep optimum balance between resort and recreational and other possible options of use of the region.

Providing in compliance to requirements of the IOC and FIFA of all infrastructure of Sochi: engineering infrastructure and power supply, modern means of communication, transport, quality of personnel, necessary nature protection actions, tourist infrastructure, etc.) has considerably increased appeal of the region as the beach, balneological and sports and entertaining resort. The main directions of development were defined by the Resolution

*Corresponding author: Yurid2006@yandex.ru 
of the Government of the Russian Federation of 29.12.2007 No. 991 "About the Program of construction of the Olympic objects of Sochi as mountain resort” (2007).

Actions of this Program had interindustry character and affected practically all spheres of regional activity. Considerable investments have been made to the region on its infrastructure development. Accelerated construction of infrastructure facilities, their complexity, close integration of a set of various construction stages have allowed to organize the solution of objectives only due to their association within the uniform Program.

Development of the new master plan of development of the city district "City of Sochi" had been carried out by 2009 in development of the previous General plan of 1986 and taking into account tasks, which have been defined in the Programs, called above. This document was called "Development of the master plan of the city district "City of Sochi". Institute of town planning "Giprogor" and "Institute of urbanistic" also drafted Regulations on territorial planning" in 2009.

However, the special plans or programs directed to strategic objectives of further development of the region during the post-Olympic period and mainly connected with his fundamental tourist sphere haven't been developed up to standard and specially issued for the years ahead neither to, nor right after holding the Olympic Games in Sochi.

Single questions about the need of expediency of such development were considered in [1]. Based on [1-2] it is possible to allocate five types of complex actions, mainly, from regional administrations. These actions have to be aimed at the development of objects of the Olympic heritage and the solution of possible problems of delay of the development rates of the region during the post-Olympic period (Tab. 1).

Table 1. Conceptual approaches to realization of the post-Olympic heritage [3].

\begin{tabular}{|c|l|c|}
\hline $\begin{array}{c}\text { Nature of } \\
\text { actions }\end{array}$ & \multicolumn{1}{|c|}{ Features } & $\begin{array}{c}\text { Preference of } \\
\text { realization }\end{array}$ \\
\hline $\begin{array}{c}\text { The Liberally }- \\
\text { free relation }\end{array}$ & $\begin{array}{l}\text { Low activity of local and regional authorities in the solution of problems at } \\
\text { the post-Olympic stage, implicit programs of realization of the post-Olympic } \\
\text { heritage, focus on subsidizing, subsidized programs or subventions }\end{array}$ & The smallest \\
\hline $\begin{array}{c}\text { The supporting } \\
\text { policy }\end{array}$ & $\begin{array}{l}\text { Use of standard methods on attraction of investments, the enterprises and } \\
\text { tourists, use of objects of heritage which is limited to their functional } \\
\text { purpose, allocation of temporary or constant structural divisions of } \\
\text { authorities or creation of other organizational educations concerning } \\
\text { realization of the post-Olympic heritage }\end{array}$ & Possible \\
\hline $\begin{array}{c}\text { The territorial } \\
\text { focused approach }\end{array}$ & $\begin{array}{l}\text { Use of standard methods on attraction of investments, the enterprises and } \\
\text { tourists, use of objects of heritage which is limited to their functional } \\
\text { purpose, allocation of temporary or constant structural divisions of } \\
\text { authorities or creation of other organizational educations concerning } \\
\text { realization of the post-Olympic heritage }\end{array}$ & High \\
\hline $\begin{array}{c}\text { Design and } \\
\text { strategic } \\
\text { orientation }\end{array}$ & $\begin{array}{l}\text { Implementation of difficult and expensive projects on reconstruction of } \\
\text { objects of the post-Olympic heritage (for example, transfer of a part of } \\
\text { objects to other regions), transposition of the Olympic effect" for a super } \\
\text { long-term outlook, focus on additional state support }\end{array}$ & Low \\
\hline $\begin{array}{c}\text { The mixed } \\
\text { approach }\end{array}$ & $\begin{array}{l}\text { Combination of different aspects of several approaches depending on market } \\
\text { conditions, creation of perspective concepts and formation of the strategy } \\
\text { based on key factors for concrete municipal unit of the region }\end{array}$ & Probable \\
\hline
\end{tabular}

In principle, in actions of regional administration during the post-Olympic period it is possible to note the separate attempts relating to each of the allocated approaches. However, actions of governing bodies of federal level in the separate directions of use of objects of the post-Olympic heritage seem to be more organized, financially provided with the long-term prospect of realization.

The post-Olympic sustainable development of the Sochi region has to be reflected in updating of the General plan of its development at the regional level. 
Necessary updating of the existing General plan has to be focused on further transformation of the post-Olympic Sochi to the excellent resort. This direction has also been earlier put in basic provisions of the General plan. Adjustment has to be surely based on agglomerative approach [1-2]. The foundation for creation of agglomeration has been laid as early as 1967 and 2009 previous in master plans. Such approach has to promote creation of complete resort agglomeration of tourist and recreational type in the region.

\section{Strategy of further long-term planning of the Sochi Resort Agglomeration (SRA) development}

\subsection{Stages of development of the General plan and SRA}

The feature of an economical geographical location of Sochi still causes existence in the region of numerous objects of the sphere of tourism and objects which activity is aimed at providing steady prospects of development of a tourist component of the region fundamentals of its economy. The principles of stability of the region and the prospect of its development as the resort agglomeration, largest in Russia, have been formulated in the General plan of development of the city of 1986. These principles have gained further development in the new General plan of 2009 [1-2].

Tasks of General plans of the city - integrated management of seaside coastal territories of the Sochi region taking into account its recreational resources and for its sustainable development. General plans of 1986 and 2009 provided harmonious development of the Sochi region as uniform resort city [1]. The interests of the state and citizens have been united in them in a whole. These interests concerned environmental issues, a city architecture, objects of tourism and development of transport, a condition of municipal services, residential areas, balneology, huge recreational opportunities of Sochi National Park, etc. The foundation of territorial division of the region into clusters as a part of the created new resort agglomeration of Sochi has been laid in these previous General plans. In addition, functional deficiencies for development of all region and its separate territorial parts have been defined [1-2].

Use of the program and target method for the solution of problems of the post-Olympic development of Sochi within updating of the existing General plan, also as well as in the previous General plans has to be aimed at further development of conditions of effective management of regional resources of the region as sea and as the mountain resort [3-5].

\subsection{Main directions of further social and economic development of the Sochi Resort Agglomeration (SRA)}

The health resort of Sochi is the largest in Russia. The role and the importance of the city as tourist center is defined by current state of its infrastructure and perspective development of its city-forming branch - tourist. Further growth of its prestigiousness, transformation of Sochi into modern competitive Spa-hotel, the business and tourist center have to become a main goal of updating of the master plan of development of the city.

It is necessary to continue the further solution of questions of updating and development of the existing General plan of resort agglomeration during the post-Olympic period $[2,6]$. Perspective models of economic, social, cultural and ecological development of the resort region have to become a basis for improvement of the General plan of Sochi as resort town of the international level. New post-Olympic opportunities have to form favorable infrastructure of transformation of Sochi into the excellent resort and further. They have to become a basis for updating of the existing General plan during the subsequent period. 
The town-planning knots, historic facts, objects of architecture, of the transport infrastructure having the historical value and which are of interest to the world community have to serve as basic elements of the designed new architectural and planning structure. They will provide competition and investment attractiveness of the developing resort agglomeration of Sochi [1, 2].

The forecast of social and economic development of the city of Sochi during the postOlympic period makes assumptions that in the predicted period there will be more beneficial effect of external and internal factors, the economic environment and an economic situation of the enterprises of the city will significantly improve, their investment activities is stirred up. The main task of the post-Olympic period consists in activization of action of all factors providing conditions for sustained economic growth for increase in welfare of the population of the city [2-6].

The predicted indicators have to be aimed at the further development in the following priority directions [1-5]:

- growth of investment attractiveness and formation of positive image of the city of Sochi;

- ensuring more effective use of natural and resource potential;

- further updating of fixed assets of branches of regional economy;

- implementation of new projects for infrastructure, further development of system of transport which in full will be able to provide needs of the region;

- ensuring effective and reliable functioning of municipal life support systems of the population of the city,

- other directions of regional development].

Further development of infrastructure of Sochi and creation of conditions for his accelerated development based on the staticized General plan for the post-Olympic period has to be a priority. The necessity of it is defined by the purpose - optimum use of the resort and recreational and natural Sochi complex, unique on the value [3-4, 7, 9-10].

The forecast of an annual gain of total volume of production of goods and services for prospect until 2030 has to be made in the concept of updating of the existing General plan. It has to be executed on the basis of economic and situation analysis of position of the region for last post-Olympic period and with use of materials of the previous General plan and Program of social and economic development of Sochi.

The favorable social and economic situation has been developed in Sochi after holding the Olympic Games of 2014 and matches of the 2018 FIFA World Cup of.

The total volume of production of goods and services has to increase in Sochi according to the forecast $[7,8]$ almost twice by 2030 . The advancing growth rates - more than by 4 times are predicted in the sphere of tourist and excursion and sanatorium and improving service of the population and branches accompanying them (passenger transport, communication, medicine, financial service, etc.).

The predicted advancing growth rates of range of services in the sphere of tourist and recreational and sanatorium and improving activity, decrease in a role of unauthorized participation of the private sector in service of tourists and vacationers finally will lead to changes in structure of consumption in general. Redistribution towards increase in specific weight of paid services to the population (from 17,4\% to $35 \%$ of 2030 ) and turnover of public catering (from $6 \%$ to $8 \%$ ) will happen in branches of the non-productive sphere at simultaneous decrease in a share of retail trade turnover (from 53,5\% to 35\%). [2-8, 10].

The multi-purpose and highly skilled system of service in various types and forms of recreational activity has to be developed in the nearest future. The infrastructure conditions providing gradual replacement of chaotic consumption of entertaining resources of the region with the ordered system of their use have been already created in the city. 
Increase in a share of the busy population from total of inhabitants in all branches of urban economy has to increase from $52 \%$ up to $80-85 \%$ by 2030 . It will be connected, first, with development of economy of the resort, secondly, with legalization of essential quantity of objects in private business, growth of industrial production and expansion of a field of activity of small business. It is necessary to develop new strategies and comprehensive long-term programs of efforts on mobilization of development of the state and business in the resort in the conditions of these changes and tendencies. It is possible to refer to them, for example, fuller development of all climatic factors of the city, updating of resort and recreational branch and construction on this base of new health resorts, the organization of rehabilitation offices and the multipurpose medical centers.

Creation of the new versatile centers of resort service and re-equipment of already available institutions will allow solving a problem of seasonality of functioning of resort base of the city. The main objective is a planning and coordination of further development of the resort of Sochi, including development of the concept and local plan of the territory, planning and coordination of construction of infrastructure, formation of the budget of the project, search of sources of financing, involvement of private investors and partners. Judging by international experience, purposeful state investments into development of tourism can lead to essential growth in incomes of branch and volumes of private investments.

The main objective is a planning and coordination of further development of the resort of Sochi including development of the concept and local plan of the territory, planning and coordination of construction of infrastructure, formation of the budget of the project, search of sources of financing, involvement of private investors and partners. Judging by international experience, purposeful state investments into development of tourism can lead to essential growth in incomes of branch and volumes of private investments.

Development of the tourism industry and transport are important results at assessment of social and economic consequences for Sochi from holding XXII Winter Olympic games, the XI Para-Olympic games of 2014 and the 2018 FIFA World Cup of. Attraction of additional investments into the hotel sector of the city and the tourism industry has allowed creating the additional jobs calculated on the expected growth of inflow of tourists in the future. Growth of tourist flow extends also to the close post-Olympic period, and prospect as the result of further development of tourist and transport infrastructure [2-10]. Increase in tourist flow and expenses of tourists optimum affects economy of all region (table 2).

Table 2. Recreational capacity of the resort town of Sochi on prospect $[3,5]$.

\begin{tabular}{|c|l|c|c|c|}
\hline № & \multicolumn{1}{|c|}{ City- Sochi } & 2014 & 2030 & 2050 \\
\hline 1 & Population, thousand persons & 418,9 & 454 & 510 \\
\hline 2 & $\begin{array}{l}\text { The additional single population - a maximum in August, one } \\
\text { thousand people, including: }\end{array}$ & 600 & 600 & 450 \\
\hline 3 & $\begin{array}{l}\text { Single stay in mini-hotels of the private sector, one thousand } \\
\text { persons }\end{array}$ & 450 & 400 & 200 \\
\hline 4 & Hotels, sanatoria and boarding houses, thousand places & 150 & 200 & 250 \\
\hline 5 & Hotels, sanatoria and boarding houses, thousand sq. m & 4125 & 6250 & 7813 \\
\hline 6 & Reception of tourists in a year, one thousand persons & 4500 & 5920 & 7450 \\
\hline 7 & $\begin{array}{l}\text { The seasonal workers occupied in construction, one thousand } \\
\text { persons }\end{array}$ & 50 & 30 & 25 \\
\hline 8 & $\begin{array}{l}\text { Service personnel of hotels, sanatoria and boarding houses - } \\
\text { everything, one thousand persons }\end{array}$ & 45 & 80 & 100 \\
\hline 9 & $\begin{array}{l}\text { Service personnel of mini-hotels of the private sector, thousand } \\
\text { persons }\end{array}$ & 45 & 40 & 20 \\
\hline 10 & Total the single maximum load on the territory & 1069 & 1084 & 985 \\
\hline
\end{tabular}




\section{Directions of development of the Sochi resort and tourist complex (RTC) as bases of the Sochi resort agglomeration}

Now it is necessary to carry out continuous monitoring of the world tourist information space since the competitive relations in the modern tourist market overstepped all national limits long ago.

Definition of the major services in the resort having the greatest appeal and competitiveness at world level has a basic role in this regard. The strategy of development for a resort and tourist complex directed to transformation of the city of Sochi into the tourist center of world level has to be connected with the following main directions [7-10]:

- development of Sochi as the world-class resort and rehabilitation center having for this purpose unique balneological resources;

- development of the mountain types of tourism connected with development of mountain and foothill territories and most using unique natural landscapes;

- development of the business tourism giving the chance of combination of fruitful work with comfortable rest in the conditions of the Mediterranean subtropical climate. The available necessary conference rooms, and new exhibition complexes based on Olympic venues contribute to its development.

All sports Olympic base with guarantee it is also very profitable, it is operated all the year round at such approach. This Olympic base is used not only in sports but also in the business and rehabilitation purposes.

Such circumstance and such approach under which the relation to resort ecology and to all its ecosystem in effect cardinally changes at introduction of the planned transformations of town planning. It is at implementation of these approaches in the General scheme only about the environmentally friendly tourist center of world value and about application during his creation, first, of environmentally friendly technologies, including in all branches of municipal economy of Sochi and at construction of new objects in the region.

The generalizing scheme of the Sochi resort and tourist complex (RTC) includes natural sights, balneological and hydrological resources, cultural and historical and sporting venues and dislocation of placement of all health resorts, hotels. The scheme well shows that taking into account the most city agglomeration of Sochi, the resort town has been obviously overloaded today. The acute shortage of resort and recreational areas (about 700 800 hectares) is available in the developed city line and in all coastal zone. Ecological situation in the territories adjacent to a transport corridor of Sochi is inadmissible for the resort town. Besides, problems of environmental protection of the resort have closely intertwined with carrying out chaotic construction of buildings, especially high-rise construction, in the territories adjoining the coast and the only transport corridor. It is especially obvious in the central part of the city in which the leading resorts of the resort and where historically there pass main touristic flows are located.

Separate environmental, social, transport, engineering and other problems even after the huge infrastructure changes connected with holding the Olympic Games even more have become aggravated. As a result, these problems bring a situation in the resort in essence to line behind which the real crisis is looked through. It is recorded by inspections of tourist flows in which the discomfort, obvious and inadmissible for modern tourist economy, in the conditions of stay of tourist flows in Sochi is revealed. If to consider that all current construction is generally developed in the city on the only thoroughfare of the resort town which is already overloaded, then quite definitely in the next several years it is possible to predict inevitable stagnation of development of the Sochi region, with all that it implies from here social and economic consequences.

The necessity of redistribution of tourist flow for agglomeration of the resort of Sochi follows from this. 
Problems of development of new town-planning approaches to questions of development of the resort of Sochi, providing town-planning bases of competitiveness of the Sochi agglomeration taking into account modern requirements become at the same time very relevant. It follows from tendencies of development of the modern world tourism.

It is possible to carry to such approaches:

1. New decisions on the planning organization of a complex have to be considered and offered in development of the Concept of the General plan of the city. Accounting of the post-Olympic realities is necessary. These decisions have to raise the questions of functional zoning; more rational placement of objects of the tourism industry ensuring functioning and further development alpine skiing, mountain, SPA and sea resorts accompanying their infrastructures. These new decisions have to consider how current situation in development of the Sochi resort agglomeration and the prospects of its development.

The new proposed solutions and offers in development of the Concept of the General plan of the city have to be based on the analysis of new post-Olympic conditions in various contexts of development (natural, anthropogenic, engineering). They have to consider all difficulties of the numerous influencing factors and to be coordinated to the purposes of further complex development of unique mountain and sea recreational and resort agglomeration.

The system of subjects to recreational appointment unique on a variety and level of connectivity forming a basis of new Sochi resort agglomeration has to be created as a result of such new correcting decisions.

2. Proceeding from new post-Olympic realities, the concept of the post-Olympic townplanning development has to be developed further based on the principles of sustainable development of the territory.

3. Improvement of a spatial framework of the territory, which during the post-Olympic period has received the specific features, has to become the main direction of the territorial organization of agglomeration.

The planning structure of the Sochi agglomeration in the previous General schemes was defined by the main and minor natural planning elements of the territory: the seashore, floodplains of the rivers, hillsides, transport axes, the centers and zones with various intensity of their economic development. Such structure reflected the developed interaction of the city and sea. This interaction was expressed in formations of linear planning solution for the region. Placement of the settlements and settlements kind of strung to the line of the coastline of the railroad going lengthways has been connected with historically developed mainly seasonal and sea and balneological purpose of the resort.

Such approach has predetermined many shortcomings, which adversely influence conditions of town-planning development of the city. Separate elements of its infrastructure were extremely overloaded as the result of it.

Development of two Olympic clusters, other objects of the Olympic construction in the general planning structure of Sochi has given a powerful impulse to the meridional direction in development of the Sochi resort complex. New principles of territorial division into districts and macro zoning, such, for example, as: priority formation of meridian decisions in planning of development of resort agglomeration in comparison with linear planning of the region along the seashore, complex accounting of natural, balneological, planning, engineering and infrastructure factors has to be considered in the Concept of development of the General scheme. It assumes obligation of consideration when updating the General scheme of new approaches to development of all Sochi resort agglomeration, first inclusions of the meridional directions of expansion of the city in creation of the complete harmonious planning organization of this urbanized territory. 
4. Architectural and planning organization of the territory. Accounting of unique climatic, historical and cultural, social and demographic resources of the mountain and sea resort, new requirements to quality of the environment of activity to a recreation and tourism is necessary for realization of problems of transformation of Sochi into the excellent resort at correction of architectural planning solutions.

Therefore, in the Concept of development of the region and in updating of the new Master plan of creation of resort agglomeration it is necessary to put the following basic offers:

- orientation to further formation of a sea facade of the resort (sea cruise and coasting moorings and development of coasting swimming, walking embankments, coastal hotels, high-quality housing and public and business estate, entertaining, leisure and business complexes, yacht-clubs, etc.);

- building of the territory of municipal districts of the city has to include further reconstruction and restoration of areas of historical building, elimination of still existing low-quality building, new construction of the developed centers of service and transport infrastructure, landscape improvement, expansion of highways, formation of the expressive front of building turned to the sea, the obligatory device of parking, creation of the cascade of the planted trees and shrubs spaces and improvement of territories carrying out a complex of nature protection actions and many other correcting actions.

6. The combination of unique geo-botanical and zoological resources which are characterized by high degree of a biodiversity rich balneology and hydro-mineralogy and also complexity of geographical, hydrological, technical and geological conditions causes simultaneous presence of a large number of restrictions at city planning. It significantly complicates territorial development of the city of Sochi.

Taking into account the above in updating of the Concept of development of the General plan the borders of zones with special conditions of use of territories are in addition have to be carefully investigated and allocated.

The option of the solution of a serious ecological-town-planning problem of the resort town - functioning of the railroad in the seaside zone, which is sharply lowering quality of rest and inflow of investments into Sochi, must be taken into account with the concept of development of the general plan.

Decisions of the concept of development of the master plan priority development of resort and balneological functions has to provide improvement of quality of life, rest, treatment of recreant and local population in a seaside zone with formation of compact zones of resettlement in a foothill zone and orientation on improvement of an ecological situation in the resort town.

The problem of development of Sochi consists in the conflict of three contradictory functions: resort, movement of the population and nature protection. Success of development will depend on the correct ecology-and socially caused choice of strategy of formation of a resort and tourist complex as city-forming branch.

Sochi can be developed as the world sports, improving, rehabilitation tourist center at the scientifically based and system focused approach to updating of the General plan [6]. In that case, guaranteed economic and year-round use in necessary parameters of the sports infrastructure left after the Olympic Games for needs and the resort and city. Considering need of the post-Olympic rehabilitation of all Sochi in view of ecological and technological aspect of such strategy also serious opportunities of development of Sochi as scientific center and scientific testing ground are defined. The purpose of such development is to provide break in the field of engineering ecology, town planning, improvement of the person and the nature, etc.

Intensive development of a natural complex of the Sochi resort agglomeration will demand the town-planning concept with revision of the principles of functional zoning and 
the organization of land use traditional for the General plan of the city with obligatory observance of the modes of building and operation carrying out monitoring and the maintenance of service of ecological safety in borders of an ecological framework of the territory.

\section{Conclusions}

When working on updating of the General plan of the region taking into account the purposes of his sustainable development it is necessary:

- to make the complex and detailed analysis of a current (post-Olympic) state of the region (to create the basic plan);

- to process the main city-forming forecasts directions;

- to develop a modern town-planning resort component of the General plan on a basis from cluster forecasting;

- to reconsider intra city zoning and division into districts taking into account the changes which have happened during the post-Olympic period;

- to reconsider justification of planning solutions of small settlements (other scale of specification and other extent of study of the proposed solutions is necessary);

- it is necessary to carry out profound development of a transport framework of the city and region with study of its main knots;

- taking into account the law on strategic planning of the region, the city administration is obliged to develop new strategy of social and economic development during the postOlympic period. Adaptation of the corrected General plan together with the new strategy of social and economic development of Sochi during the post-Olympic period in one document is necessary.

The following conclusions can be drawn based on the above-mentioned [2-10]:

1. Maintaining its post-Olympic prestigiousness and competitiveness and his subsequent transformation into the modern Spa-resort, business, sports and tourist center of world level providing the maximum growth of own profitable base has to become a main goal of further development of the resort town of Sochi.

2. The advancing growth rates have to be predicted in the sphere of tourist and excursion and Spa-improving service of the population and branches accompanying them (passenger transport, communication, medicine, finance and the credit, public catering, services industry, etc.) by 2030 . The possibility of combination of rest with business activity, change of recreational infrastructure, active development of tourist, sports spheres and winter recreation facility will lead up to $80-90 \%$ to increase in a share of the objects working all the year round.

3. Increase in a share of the busy population in all branches of city economy from $52 \%$ to $75-80 \%$ (at working-age) has to come from total number by 2030 . It has to be connected, first, with development of resort economy, legalization of a significant amount of jobs in private business, growth of industrial production, expansion of a field of activity of small business. It is necessary to plan in addition more than 100 thousand jobs for prospect till 2030 .

4. It is necessary to reduce considerably fluctuations between year-round and seasonal employment of the population. If in 2007 during the summer period, the number of places of work increased almost for $50 \%$ of rather average annual level then by 2030 this gap has to decrease to $10 \%$.

5. The average per capita income of the population predicted for 2030 has to increase and approach the current level of income of the developed countries of Western Europe.

6. Further withdrawal from the downtown and resort areas of the enterprises, which are not meeting ecology-health requirements, has to be provided in updating of the General 
plan. Improvement of an ecological situation, release of the territories suitable for townplanning development and a recreation has to result from carrying out.

Basic changes in a configuration and structure of resort agglomeration including by intensive development of the meridian directions, formation of the new planning structures united by the modernized system of communications have to be provided in the Concept of further development of the region.

It is necessary to consider the most essential use of a coastal cluster and development of sea zones (design and construction of the yacht harbor, modular beaches) and also gradual withdrawal of construction from the sea coast in a little mastered but not less attractive foothill zones of the city and placement new recreational facilities in the depth of the territory on prospect [2-10].

Further withdrawal from the downtown and coastal resort areas of the enterprises, which don't meet the ecological, and health requirements has to be provided in updating of the Master plan. Improvement of an ecological situation, release of territories, which are suitable for town-planning development.

\section{References}

1. O.F. Kozinskij, O.V. Kozinskaya, V.N. Sharafutdinov Importance of the Olympic heritage in the pilot project of a Sochi and Tuapse resort agglomeration. Moscow: Architecture and construction J., 2, 86 - 92 (2015)

2. M.D. Goryachko, V.L. Bartn, R.P. Kolosova, E.A. Chernyh, Olimpijskoe nasledie Sochi (M.ZH. OLMA, 2014)

3. S.I Mishulina, Modern problems of service and tourism J., 4, 75 - 87 (2014)

4. A.Yu. Vega The mechanism of coordination of ecology and economic interests by preparation and holding the Winter Olympic Games of 2014. Moscow: Environmental Economy J., 4, 96 - 131 (2009)

5. I.M. Potravnyj, H.H. Mal'ceva? A.Yu. Vega Methodical approaches to assessment of efficiency of actions when constructing facilities in especially protected natural territories and in resort areas. Moscow: Environmental Economy J., 3, (2010)

6. D.Yu. Kukushkin The Olympic heritage as a factor of social and economic development of the tourist territory (on the example of Sochi), Avtoreferat dissertacii (SGU, Sochi, 2017)

7. M.K. Kovaleva, Vestnik AGU J., 2(180), 78 - 84 (AGU, Maykop, 2016)

8. I.M. Potravnyj, A.Yu. Vega Proc. of the scientific and practical conference "Problems of Regional Economy in the conditions of Sustainable Development”, Kirov: 4.1, 325 328 (2007)

9. A.N. Kudaktin, V.N. Kondrat'ev Problemy i perspectivy postolimpiyskogo razvitiya Sochi. Mezhdunarodnyj zhurnal ehksperimental'nogo obrazovaniya J., 8-3, 339 - 342 (2015)

10. A.V. Kuleshova Rekreacionnyj potencial sochinskogo regiona v sisteme social'nogo razvitiya Rossijskoj Federacii. Moscow, Sociologiya social'noj sfery J., 5, 60 - 66 (2011) 